\title{
Adaptation of Cupriavidus metallidurans CH34 to Toxic Zinc Concentrations Involves an Uncharacterized ABC-Type Transporter
}

\author{
Rob Van Houdt ${ }^{1, * \mathbb{C}}$, Joachim Vandecraen ${ }^{1,2}$, Natalie Leys ${ }^{1}$, Pieter Monsieurs ${ }^{1,+}$ and Abram Aertsen ${ }^{2}$ \\ 1 Microbiology Unit, Interdisciplinary Biosciences, Belgian Nuclear Research Centre (SCK CEN), \\ 2400 Mol, Belgium; joachim.vandecraen@sckcen.be (J.V.); nleys@sckcen.be (N.L.); pmonsieu@sckcen.be (P.M.) \\ 2 Laboratory of Food Microbiology, Department of Microbial and Molecular Systems, \\ Faculty of Bioscience Engineering, Katholieke Universiteit Leuven, 3000 Leuven, Belgium; \\ abram.aertsen@kuleuven.be \\ * Correspondence: rvhoudto@sckcen.be \\ + Current address: Institute of Tropical Medicine, 2000 Antwerp, Belgium.
}

Citation: Van Houdt, R.; Vandecraen, J.; Leys, N.; Monsieurs, P.; Aertsen, A. Adaptation of Cupriavidus metallidurans $\mathrm{CH} 34$ to Toxic Zinc Concentrations Involves an Uncharacterized ABC-Type Transporter. Microorganisms 2021, 9, 309. https://doi.org/10.3390/ microorganisms 9020309

Academic Editor: Sylvie Chevalier

Received: 6 January 2021

Accepted: 31 January 2021

Published: 2 February 2021

Publisher's Note: MDPI stays neutral with regard to jurisdictional claims in published maps and institutional affiliations.

\begin{abstract}
Cupriavidus metallidurans $\mathrm{CH} 34$ is a well-studied metal-resistant $\beta$-proteobacterium and contains a battery of genes participating in metal metabolism and resistance. Here, we generated a mutant $\left(\mathrm{CH} 34^{\mathrm{ZnR}}\right)$ adapted to high zinc concentrations in order to study how $\mathrm{CH} 34$ could adaptively further increase its resistance against this metal. Characterization of $\mathrm{CH} 34^{\mathrm{ZnR}}$ revealed that it was also more resistant to cadmium, and that it incurred seven insertion sequence-mediated mutations. Among these, an IS1088 disruption of the $g l p R$ gene (encoding a DeoR-type transcriptional repressor) resulted in the constitutive expression of the neighboring ATP-binding cassette (ABC)-type transporter. GlpR and the adjacent ABC transporter are highly similar to the glycerol operon regulator and ATP-driven glycerol importer of Rhizobium leguminosarum bv. viciae VF39, respectively. Deletion of $g l p R$ or the $\mathrm{ABC}$ transporter and complementation of $\mathrm{CH} 34^{\mathrm{ZnR}}$ with the parental $g l p R$ gene further demonstrated that loss of GlpR function and concomitant derepression of the adjacent $A B C$ transporter is pivotal for the observed resistance phenotype. Importantly, addition of glycerol, presumably by glycerol-mediated attenuation of GlpR activity, also promoted increased zinc and cadmium resistance in the parental CH34 strain. Upregulation of this ABC-type transporter is therefore proposed as a new adaptation route towards metal resistance.
\end{abstract}

Keywords: Cupriavidus metallidurans; zinc resistance; cadmium resistance; directed evolution; ABC transporter

\section{Introduction}

Metal homeostasis is important for all bacteria since they have to react swiftly to both the scarcity and excess of either essential or toxic metals [1-3]. To defend themselves against high metal toxicity, bacteria depend on multiple resistance mechanisms, including efflux pumps, proteins changing the oxidation state of metals, and intra- or extracellular sequestration of metals [4-7]. In addition, extracytoplasmic function (ECF) sigma factors play an important role in the response to environmental stressors as well as in metal homeostasis [8].

One of the essential metals is zinc, which occurs naturally in air, water, rocks, and soil. The average natural zinc level in the Earth's crust is $70 \mathrm{mg} / \mathrm{kg}$ (dry weight), generally ranging between 10 and $300 \mathrm{mg} / \mathrm{kg}$ [9]. However, zinc has been concentrated to much higher levels at some locations, either by natural geological and chemical processes or through anthropogenic interventions because of the wide use of zinc compounds in industry, agriculture, and medicine [10-16]. Despite its essential role as a trace element in various biological processes, including proper functioning of specific enzymes, stabilization 
of DNA, and expression of genes [17], excess zinc has significant toxicity and acts as a potent disrupter of biological systems [18]. This duality of zinc properties requires a tight regulation of its intracellular homeostasis.

Cupriavidus metallidurans $\mathrm{CH} 34$ was one of the first bacteria to be isolated from industrial sites characterized by an extremely high metal content [19] and contains an unprecedented number of genes involved in the resistance and processing of metals [7]. C. metallidurans strains do not contain a high-affinity zinc uptake system like the ATPbinding cassette $(\mathrm{ABC})$ uptake system ZnuABC from Escherichia coli [20]. Instead, uptake of zinc is accomplished by a set of highly redundant metal cation uptake systems with only minimal selectivity. In strain $\mathrm{CH} 34$, the only known import system with some specificity for zinc is ZupT [21,22], which is needed to deliver zinc under conditions of low availability [23]. The expression of zupT is upregulated under conditions of zinc starvation and repressed by FurC when sufficient zinc is present [24]. Deletion of zupT results in numerous defects caused by disturbed zinc homeostasis at lower and higher zinc concentrations [22].

C. metallidurans $\mathrm{CH} 34$ accomplishes metal detoxification by the concerted action of efflux systems, which may be followed by metal sequestration or complexation [25-29]. Various transporters remove excess zinc either from the cytoplasm or the periplasm. The most important zinc resistance operon is the $c z c$ cluster on megaplasmid pMOL30 $[7,19,26,30,31]$. The high-level metal resistance system Czc mediates the efflux of $\mathrm{Co}^{2+}, \mathrm{Zn}^{2+}$ and $\mathrm{Cd}^{2+}$, and loss of pMOL30 results in a drastically reduced zinc resistance [19]. The $c z c$ determinant is organized into two divergently transcribed gene clusters, i.e., czcNICBADRSE and $c z c P$. The first cluster encodes CzcCBA belonging to the heavy metal efflux (HME)Resistance-nodulation-division (RND)-driven efflux systems [32] and is comprised of three components spanning both outer and cytoplasmic membrane with an outer membrane protein $(\mathrm{CzcC})$, a membrane fusion protein $(\mathrm{CzcB})$, and a substrate-binding inner membrane transporter (CzcA) [33,34]. RND-driven efflux systems are responsible for the export of their substrates from the periplasm to the outside of the cell [35-38]. The $c z c D$ gene codes for a secondary transport system belonging to the Cation Diffusion Facilitator (CDF) family [27]. The second cluster codes for $\mathrm{CzcP}$, a $\mathrm{P}_{\mathrm{IB} 4}$-type ATPase, which functions as a resistance enhancer exporting $\mathrm{Zn}^{2+}$ much more rapidly than $\mathrm{P}_{\mathrm{IB} 2}$-type ATPases, but it relies on the action of the latter to provide a basic resistance level [38]. The $c z c$ operon is zinc-inducible and under the control of the two-component regulatory system of CzcS (a histidine sensor kinase) and CzcR (a response regulator) [30,39]. However, a complex interplay exists between the plasmid-borne regions and chromosomal metal resistance clusters in zinc resistance. Two other efflux systems are inducible by zinc, i.e., the $\mathrm{P}_{\mathrm{IB} 2}$-type ATPases ZntA and CadA (both located on the chromosome), but their zinc induction is prevented in the presence of the $c z c$ operon [40]. Two more proteins of the CDF family, i.e., DmeF and FieF, which are both chromosomally encoded, were described to be mainly involved in cobalt and iron homeostasis, respectively, but have broad substrate spectrum and can probably also transport zinc [41]. In addition, C. metallidurans harbors a second RND transporter involved in zinc efflux, namely the chromosomally encoded Zne transporter $[42,43]$. Although this transporter is highly specific for zinc, it seems to have a dedicated function in zinc homeostasis and not in resistance to high zinc concentrations as the plasmid-free strain AE104 is zinc-sensitive [44]. The CDF and ATPase efflux systems transport their substrate from the cytoplasm to the periplasm, where RND-driven efflux systems will export these metals to the outside of the cell $[8,27]$.

While the current zinc resistance mechanisms of $\mathrm{CH} 34$ have been well established, much less is known about its adaptive potential in the face of zinc stress. In this study we generated a mutant adapted to high zinc concentrations in order to shine a light on possible adaptive changes in $\mathrm{CH} 34$ 's genome. As such, a novel determinant underlying increased zinc resistance could be identified. 


\section{Materials and Methods}

\subsection{Strains, Media, and Culture Conditions}

The bacterial strains and plasmids used in this study are listed in Tables 1 and 2. C. metallidurans was routinely cultured at $30^{\circ} \mathrm{C}$ in Tris-buffered mineral medium $(6.06 \mathrm{~g} / \mathrm{L}$ Tris/HCl, $4.68 \mathrm{~g} / \mathrm{L} \mathrm{NaCl}, 1.49 \mathrm{~g} / \mathrm{L} \mathrm{KCl}, 1.07 \mathrm{~g} / \mathrm{L} \mathrm{NH}_{4} \mathrm{Cl} ; 0.43 \mathrm{~g} / \mathrm{L} \mathrm{Na}_{2} \mathrm{SO}_{4}, 0.2 \mathrm{~g} / \mathrm{L}$ $\mathrm{MgCl}_{2} \cdot 6 \mathrm{H}_{2} 0,0.03 \mathrm{~g} / \mathrm{L} \mathrm{CaCl}_{2} \cdot 2 \mathrm{H}_{2} 0,0.04 \mathrm{~g} / \mathrm{L} \mathrm{Na}_{2} \mathrm{HPO}_{4} \cdot 2 \mathrm{H}_{2} \mathrm{O}, 4.8 \mathrm{mg} / \mathrm{L} \mathrm{Fe}(\mathrm{III})(\mathrm{NH} 4)$ citrate; $144 \mu \mathrm{g} / \mathrm{L} \mathrm{ZnSO} \cdot 7 \mathrm{H}_{2} \mathrm{O}, 99 \mu \mathrm{g} / \mathrm{L} \mathrm{MnCl}_{2} \cdot 4 \mathrm{H}_{2} \mathrm{O}, 62 \mu \mathrm{g} / \mathrm{L} \mathrm{H}_{3} \mathrm{BO}_{3}, 190 \mu \mathrm{g} / \mathrm{L} \mathrm{CoCl} \cdot 6 \mathrm{H}_{2} \mathrm{O}$, $\left.17 \mu \mathrm{g} / \mathrm{L} \mathrm{CuCl} 2 \cdot 2 \mathrm{H}_{2} \mathrm{O}, 24 \mu \mathrm{g} / \mathrm{L} \mathrm{NiCl}_{2} \cdot 6 \mathrm{H}_{2} \mathrm{O}, 36 \mu \mathrm{g} / \mathrm{L} \mathrm{Na}_{2} \mathrm{MoO}_{4} \cdot 2 \mathrm{H}_{2} \mathrm{O}\right)$ supplemented with $0.2 \%(w / v)$ sodium gluconate (MM284). Escherichia coli strains were routinely cultured at $37^{\circ} \mathrm{C}$ in Lysogeny broth (LB). Liquid cultures were grown in the dark on a rotary shaker at $150 \mathrm{rpm}$. For culturing on agar plates, $2 \%(w / v)$ agar (Thermo Scientific, Oxoid) was added. When appropriate, the following chemicals (Sigma-Aldrich or Thermo Scientific) were added to the growth medium at the indicated final concentrations: kanamycin $(50 \mu \mathrm{g} / \mathrm{mL}$ for E. coli $\left(\mathrm{Km}^{50}\right)$ or $1500 \mu \mathrm{g} / \mathrm{mL}$ for C. metallidurans $\left.\left(\mathrm{Km}^{1500}\right)\right)$, tetracycline $(20 \mu \mathrm{g} / \mathrm{mL}$ $\left.\left(\mathrm{Tc}^{20}\right)\right)$, chloramphenicol $\left(30 \mu \mathrm{g} / \mathrm{mL}\left(\mathrm{Cm}^{30}\right)\right), \mathrm{Zn}^{2+}(0.3,12,24$, or $25 \mathrm{mM}$ as zinc sulfate heptahydrate), $\mathrm{Ni}^{2+}\left(1.25,2.5\right.$, or $5 \mathrm{mM}$ as nickel chloride hexahydrate), $\mathrm{Cd}^{2+}(1,1.5,2,3$, or $4 \mathrm{mM}$ as cadmium chloride hemipentahydrate), $\mathrm{Co}^{2+}(1.25,2.5$, or $5 \mathrm{mM}$ as cobalt chloride hexahydrate), 5 -bromo-4-chloro-3-indolyl- $\beta$-galactopyranoside (X-Gal; $40 \mu \mathrm{g} / \mathrm{mL}$ ), and isopropyl $\beta$-D-1-thiogalactopyranoside (IPTG; $0.1 \mathrm{mM}$ ). Glycerol (Merck Millipore) was added to MM284 at a final concentration of $1 \%(w / v)$.

Table 1. Strains used in this study.

\begin{tabular}{|c|c|c|}
\hline Strain & Genotype/Relevant Characteristic $^{1}$ & References $^{2}$ \\
\hline \multicolumn{3}{|c|}{ Cupriavidus metallidurans } \\
\hline $\mathrm{CH} 34$ & pMOL28 pMOL30 & [19] \\
\hline $\mathrm{CH} 34^{\mathrm{ZnR}}$ & pMOL28 pMOL30; increased resistance to $\mathrm{Zn}^{2+}$ & This study \\
\hline $\mathrm{CH} 34 \Delta g l p R$ & $g l p R$ replaced by tet, $\mathrm{Tc}^{\mathrm{R}}$ & This study \\
\hline $\mathrm{CH} 34 \Delta 29-34$ & Rmet_2229 to Rmet_2234 replaced by tet, $\mathrm{Tc}^{\mathrm{R}}$ & This study \\
\hline $\mathrm{CH} 34^{\mathrm{ZnR}} \Delta 29-34$ & Rmet_2229 to Rmet_2234 replaced by tet, $\mathrm{Tc}^{\mathrm{R}}$ & This study \\
\hline Escherichia coli & $\begin{array}{c}\text { mcrA } \Delta(\text { mrr-hsdRMS-mcrBC, modification-, } \\
\text { restriction-) } \$ 80 l a c Z \Delta \mathrm{M} 15 \Delta \text { lacX74 recA1 araD139 } \\
\Delta(\text { ara-leu }) 7697 \text { galU galK rpsL endA1 nupG }\end{array}$ & Eurogentec \\
\hline HB101 & $\begin{array}{l}\mathrm{F}^{-} \text {mcrB mrr hsdS20(rB- mB-) recA13 leuB6 ara-14 } \\
\text { proA2 lacY1 galK2 xyl-5 mtl-1 rpsL20 glnV44 } \lambda-\end{array}$ & $\mathrm{Lab}$ \\
\hline
\end{tabular}

Table 2. Plasmids used in this study.

\begin{tabular}{|c|c|c|}
\hline Strain & Genotype/Relevant Characteristic ${ }^{1}$ & References $^{2}$ \\
\hline pRK600 & Helper plasmid; $\mathrm{Cm}^{\mathrm{R}}$ tra & Lab \\
\hline pBBR1MCS2 & lac $\mathrm{Z} \alpha \mathrm{Km}^{\mathrm{R}}$ ori $\mathrm{pBBR} 1$ oriT & [45] \\
\hline pBBR-glpR & $g l p R$ in $\mathrm{pBBR} 1 \mathrm{MCS} 2$ & This study \\
\hline pBBR-glpR $R^{\mathrm{R}}$ & $g l p R:: I S 1088$ in pBBR1MCS2 & This study \\
\hline pACYC184 & $\mathrm{Cm}^{\mathrm{R}} \mathrm{Tc}^{\mathrm{R}} \mathrm{p} 15 \mathrm{~A}$ ori & [46] \\
\hline $\mathrm{pK} 18 \mathrm{mob}$ & lac $\mathrm{Z} \alpha \mathrm{Km}^{\mathrm{R}}$ oriT oriV & [47] \\
\hline $\mathrm{pglpR}$ & $g l p R$ in $p K 18 m o b, \mathrm{Km}^{\mathrm{R}}$ & This study \\
\hline pRmet_2229-34 & Rmet_2229-2234 in pK18mob, $\mathrm{Km}^{\mathrm{R}}$ & This study \\
\hline pglpR::tet & glpR::tet in $\mathrm{pK} 18 \mathrm{mob}, \mathrm{Tc}^{\mathrm{R}} \mathrm{Km}^{\mathrm{R}}$ & This study \\
\hline pRmet_2229-34::tet & Rmet_2229-2234::tet in pK18mob, $\mathrm{Tc}^{\mathrm{R}} \mathrm{Km}^{\mathrm{R}}$ & This study \\
\hline
\end{tabular}

\subsection{Isolation of Zinc-Resistant Mutants}

C. metallidurans $\mathrm{CH} 34$ was first cultivated in MM284 at $30^{\circ} \mathrm{C}$ until stationary phase and subsequently diluted 1:100 in MM284. Then $\mathrm{Zn}^{2+}$ was added to a final concentration 
of $12 \mathrm{mM}$. After four days of growth at $30^{\circ} \mathrm{C}, 10^{9}$ cells were pelleted and cell suspensions $(100 \mu \mathrm{L})$ of a serial tenfold dilution in saline $(0.85 \% \mathrm{NaCl})$ were spread on MM284 agar plates containing a final concentration of $24 \mathrm{mM} \mathrm{Zn}^{2+}$ and incubated at $30{ }^{\circ} \mathrm{C}$. Colonyforming units (CFU) were counted after day two and survival frequency was calculated as viable cell count on MM284 $24 \mathrm{mM} \mathrm{Zn}^{2+}$ agar plates divided by viable cell count on MM284 agar plates.

\subsection{Assessment of Zinc-Resistant Phenotype}

The susceptibility of $\mathrm{CH} 34$ and $\mathrm{CH} 34^{\mathrm{ZnR}}$ to a metal ion were determined by the minimal inhibitory concentration (MIC). The strains were cultivated in biological triplicates by inoculating $2 \mathrm{~mL}$ MM284 or MM284 supplemented with different metals with $20 \mu \mathrm{L}$ of a stationary phase $\mathrm{C}$. metallidurans $\mathrm{CH} 34$ or $\mathrm{CH} 34^{\mathrm{ZnR}}$ culture. The MIC is defined as the lowest metal ion concentration that inhibits visible growth of the culture after two days of incubation at $30^{\circ} \mathrm{C}$.

In addition, the resistance of $C$. metallidurans strains was further assessed with doseresponse growth curves, which were conducted in MM284 supplemented with different zinc or cadmium concentrations. Precultures were incubated at $30{ }^{\circ} \mathrm{C}$ until the stationary phase, diluted 1:100 in fresh medium with increasing zinc/cadmium concentrations, and incubated at $30^{\circ} \mathrm{C}$ for $72 \mathrm{~h}$. Next, the optical density at $600 \mathrm{~nm}\left(\mathrm{OD}_{600}\right)$ was determined in a 24-well cell culture plate (Flat-bottom, Greiner Bio-One, Vilvoorde, Belgium) which was placed into a CLARIOstar ${ }^{\circledR}$ (BMG LABTECH, De Meern, The Netherlands). It is noteworthy that high $\mathrm{Zn}^{2+}$ concentrations resulted in precipitation (of zinc hydroxide) in an abiotic non-inoculated control, but did not impact optical density measurements (Figure S1).

To further analyze the phenotype of $\mathrm{CH} 34^{\mathrm{ZnR}}$, the cell survival of both $\mathrm{CH} 34$ and $\mathrm{CH} 34^{\mathrm{ZnR}}$ at a high zinc concentration $\left(25 \mathrm{mM} \mathrm{Zn}^{2+}\right)$ were determined. Stationary phase cultures were 1:100 diluted in fresh MM284 or MM284 supplemented with $0.3 \mathrm{mM} \mathrm{Zn}^{2+}$ (pre-induction assay) and these subcultures were allowed to grow for two days. Afterwards, 2-mL cell suspensions (biological triplicate) were transferred to a 24-well cell culture plate and $\mathrm{Zn}^{2+}$ was added to a final concentration of $25 \mathrm{mM}$. Next, $20 \mu \mathrm{L}$ aliquots were withdrawn at different time points and cell suspensions $(100 \mu \mathrm{L})$ of a serial dilution were spread on LB agar. The CFU/mL was determined after two days of incubation at $30{ }^{\circ} \mathrm{C}$.

\subsection{Construction of Plasmids}

The $g l p R$ gene (Rmet_2235) from C. metallidurans CH34 and its zinc-resistant derivative $\mathrm{CH} 34^{\mathrm{ZnR}}$ were amplified by PCR (Phusion High-Fidelity DNA polymerase, Thermo Scientific, Aalst, Belgium) with primer pair Rmet_2235_Fw-Rv (Table S1), providing HindIII/EcoRI recognition sites. Afterwards, these PCR products were cloned as a HindIII/EcoRI fragment into $\mathrm{pBBR} 1 \mathrm{MCS} 2$. The resulting $\mathrm{pBBR}-g l p R$ and $\mathrm{pBBR}-g l p R^{\mathrm{R}}$ plasmids from E. coli DG1 transformants selected on $\mathrm{LB} \mathrm{Km}{ }^{50}$ were further confirmed by sequencing prior to conjugation (triparental with E. coli HB101 pRK600 as helper) to C. metallidurans CH34 and CH34 ${ }^{\mathrm{ZnR}}$.

\subsection{Construction of Deletion Mutant Strains}

The $g l p R$ gene (Rmet_2235) and the genes coding for the ABC-type transporter (Rmet_2229-2234) were amplified from C. metallidurans CH34 by PCR (Phusion HighFidelity DNA polymerase) with primer pairs Rmet_2235_Fw-Rv and Rmet_2229_FwRmet_2234_Rv (Table S1), respectively, providing HindIII/EcoRI recognition sites. Afterwards, these PCR products were cloned as a HindIII/EcoRI fragment into the mobilizable suicide vector $\mathrm{pK} 18 \mathrm{mob}$. The resulting pglpR and pRmet_2229-34 plasmids from E. coli DG1 transformants selected on LB $\mathrm{Km}^{50}$ were further confirmed by sequencing prior to amplifying of the flanking sequences of the RglpR or Rmet_2229-2234, respectively, by inverse PCR (Phusion High-Fidelity DNA polymerase) with primer pairs Rmet_2235_tet_Fw-Rv or Rmet_2229-2234_tet_Fw-Rv (Table S1), respectively, providing BcuI/XbaI recognition sites. At the same time the tet gene from pACYC184 [46] was amplified by PCR (Phusion High- 
Fidelity DNA polymerase) with primer pair Tet_Fw-Rv (Table S1), providing BcuI/XbaI recognition sites. Afterwards, this PCR product was cloned as a $B c u I / X b a I$ fragment into the former inverse PCR products. The resulting pglpR::tet and pRmet_2229-34::tet plasmids from $E$. coli DG1 transformants selected on LB $\mathrm{Tc}^{20} \mathrm{Km}^{50}$ were further confirmed by sequencing prior to conjugation (triparental with E. coli HB101 pRK600 as helper) to C. metallidurans $\mathrm{CH} 34$ or $\mathrm{CH} 34^{\mathrm{ZnR}}$. The resulting transformants selected on MM284 $\mathrm{Tc}^{20}$ were replica-plated on MM284 $\mathrm{Tc}^{20}$ and MM284 Km${ }^{1500}$. CH34 $\Delta g l p R:$ :tet (CH34 $\left.\Delta g l p R\right)$, CH34 $\Delta$ Rmet_2229_34::tet $(\mathrm{CH} 34 \Delta 29-34)$, and CH34 ${ }^{\mathrm{ZnR}} \Delta \mathrm{Rmet} 2229 \_34:: t e t\left(\mathrm{CH} 34^{\mathrm{ZnR}} \Delta 29\right.$ 34) cells resistant to $\mathrm{Tc}^{20}$ but sensitive to $\mathrm{Km}^{1500}$ were further confirmed by sequencing.

\subsection{Whole-Genome Gene Expression Analysis and qRT-PCR}

Whole-genome gene expression analysis of $\mathrm{CH} 34$ and $\mathrm{CH} 34^{\mathrm{ZnR}}$ was performed to examine which genes played a role in the increased zinc resistance. The strains were cultivated by inoculating $30 \mathrm{~mL}$ MM284 in biological triplicates with $300 \mu \mathrm{L}$ of an exponentially growing $\mathrm{C}$. metallidurans $\mathrm{CH} 34$ or $\mathrm{CH} 34^{\mathrm{ZnR}}$ culture at $30{ }^{\circ} \mathrm{C}$. These subcultures were allowed to grow until an $\mathrm{OD}_{600}$ value of around 0.6 was reached. Next, each subculture was immediately subdivided in 15 microcentrifuge tubes of $2 \mathrm{~mL}$ and cells were harvested by centrifugation for $2 \mathrm{~min}$ at 10,000 rpm. Supernatant was removed and the bacterial pellets were flash frozen by immersion into liquid nitrogen and kept frozen at $-80{ }^{\circ} \mathrm{C}$ at all times. RNA extraction, labeling and hybridization, microarray spotting, scanning, and data analysis were performed according to the work of [48]. The full description of the microarray data has been deposited at the Gene Expression Omnibus website (http:/ / www.ncbi.nlm.nih.gov/geo/) under accession number GSE156826.

In addition, total RNA was extracted from CH34, CH34 $\Delta g l p R$, and $\mathrm{CH} 34^{\mathrm{ZnR}}$ (similar conditions as above) and single-stranded complementary DNA (cDNA) was synthesized from $1 \mu \mathrm{g}$ total RNA using random hexamers as primers and the TaqMan Reverse Transcription Reagents (Thermo Scientific). The quantity of synthesized cDNA was measured with a NanoDrop ${ }^{\circledR} 2000$ spectrophotometer (Thermo Scientific). The expression of Rmet_2229 was analyzed by qRT-PCR using the QuantiNova SYBR Green RT-PCR kit (Qiagen, Venlo, The Netherlands) according to the manufacturer's protocol with primers qF_2229 and qR_2229. Expression was compared with that of the $16 \mathrm{~S}$ rRNA gene (Table S1). RT-qPCRs were performed with a Rotor-Gene Q (Qiagen).

\subsection{Genome Sequencing}

Whole-genome sequencing was performed to identify mutations responsible for the increased zinc-resistance of $\mathrm{CH} 34^{\mathrm{ZnR}}$. The strain was cultivated by inoculating $4 \mathrm{~mL} \mathrm{LB}$ at $30^{\circ} \mathrm{C}$, and total DNA was extracted using the QIAamp DNA Mini Kit (Qiagen). The quantity and quality of extracted DNA was measured using a NanoDrop ${ }^{\mathrm{TM}} 1000$ spec- $^{-}$ trophotometer (Thermo Scientific). Ten micrograms of DNA were sent for Illumina sequencing (Baseclear, Leiden, The Netherlands). Large insertions and deletions ( $>200 \mathrm{bp}$ ) were identified using an in-house developed software able to exploit the paired-end characteristics of the sequencing data, where either an unexpected increase of unpaired sequencing reads was used as an indicator for insertions, and an increase in the distribution of insert sizes interpreted as deletion. The Genome Analysis Toolikt (GATK) was used to identify point mutations, i.e., single-nucleotide polymorphisms (SNPs) and small indels [49,50]. Sequencing data are available within the Sequencing Read Archive (SRA) of NCBI using the accession number PRJNA658861.

\section{Results}

\subsection{Isolation and Characterization of Zinc-Resistant CH34 Derivatives}

Direct exposure of $C$. metallidurans $\mathrm{CH} 34$ to a high $\mathrm{Zn}^{2+}$ concentration $\left(24 \mathrm{mM} \mathrm{Zn}{ }^{2+}\right)$ is bactericidal, as no survivors were observed even after prolonged incubation (over two weeks). However, CH34 derivatives could be isolated on MM284 agar plates with $24 \mathrm{mM}$

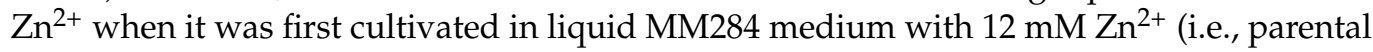


MIC). Growth in liquid MM284 medium with $12 \mathrm{mM} \mathrm{Zn}^{2+}$ was observed after four days of incubation (no visible growth after two days of incubation) and subsequent plating of this culture on MM284 agar plates with $24 \mathrm{mM} \mathrm{Zn}^{2+}$ yielded zinc-resistant $\mathrm{CH} 34$ mutants at a frequency of $2.37 \pm 0.30 \times 10^{-7}$ (calculated after two days of incubation at $30^{\circ} \mathrm{C}$ ). One mutant was further purified on MM284 and retested for its resistance. The latter, designated as $\mathrm{CH} 34^{\mathrm{ZnR}}$, exhibited an inheritable resistance phenotype and was further characterized phenotypically. Compared to its parental strain, $\mathrm{CH} 34^{\mathrm{ZnR}}$ exhibited a two-fold increased resistance to both $\mathrm{Zn}^{2+}$ and $\mathrm{Cd}^{2+}$. No increased resistance to $\mathrm{Ni}^{2+}$ and $\mathrm{Co}^{2+}$ was observed (Table 3), indicating that the involved resistance mechanism(s) can detoxify both $\mathrm{Zn}^{2+}$ and $\mathrm{Cd}^{2+}$.

Table 3. Minimal inhibitory concentration (MIC, $\mathrm{mM}$ ) of different metals determined in liquid MM284 medium for different C. metallidurans strains.

\begin{tabular}{ccccc}
\hline C. metallidurans & $\mathbf{Z n}^{2+}$ & $\mathbf{N i}^{2+}$ & $\mathbf{C o}^{2+}$ & $\mathbf{C d}^{2+}$ \\
\hline $\mathrm{CH} 34$ & 12 & 2.5 & 5 & 1.5 \\
$\mathrm{CH} 34 \mathrm{ZnR}$ & 24 & 2.5 & 5 & 3 \\
$\mathrm{CH} 34 \Delta$ glpR & 24 & 2.5 & 5 & 3 \\
$\mathrm{CH} 34 \Delta 29-34$ & 12 & 2.5 & 5 & 1.5 \\
\hline
\end{tabular}

In addition to MIC determination, inactivation dynamics in the presence of a high zinc concentration $(25 \mathrm{mM})$ were examined for the parent and its $\mathrm{CH} 34^{\mathrm{ZnR}}$ derivative (Figure 1). The fraction of surviving $\mathrm{CH} 34$ cells drastically decreased in the presence of $25 \mathrm{mM} \mathrm{Zn}^{2+}$ and no survivors could be detected after $24 \mathrm{~h}$ of incubation. Although a drastically decreased cell survival in the first hours of incubation was also shown for $\mathrm{CH} 34^{\mathrm{ZnR}}$, a fraction of the cells did survive $\left(2.85 \pm 2.07 \times 10^{-4} \mathrm{CFU} / \mathrm{mL}\right.$ after $\left.24 \mathrm{~h}\right)$. Pre-inducing the $c z c$ operon with $0.3 \mathrm{mM} \mathrm{Zn}^{2+}$ for $48 \mathrm{~h}[30,51,52]$ resulted in an increased cell survival of both the parental and zinc-resistant derivative (Figure 1). This derepression enables a fraction of the wild type cells to survive a very high concentration of $\mathrm{Zn}^{2+}$ because the Czc efflux pumps are already active before the cell encounters the toxic $\mathrm{Zn}^{2+}$ concentration $[30,51,52]$. However, cell survival for pre-induced $\mathrm{CH} 34^{\mathrm{ZnR}}$ was still higher than for pre-induced $\mathrm{CH} 34$. These observations suggest that the mutation(s) in $\mathrm{CH} 34^{\mathrm{ZnR}}$ do not target the $c z c$ operon and that its genetic background works synergistically with a zinc-induced $c z c$ operon, leading to more cells that survive.

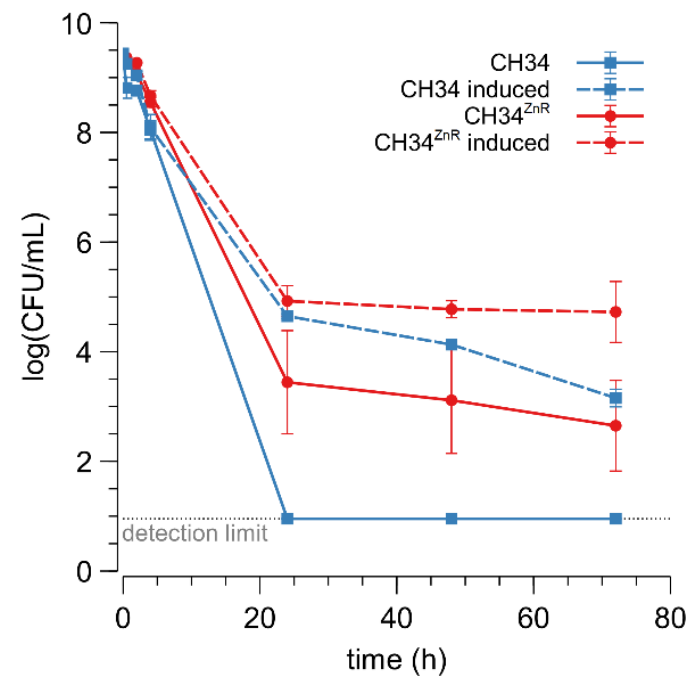

Figure 1. Cell survival upon exposure to $25 \mathrm{mM} \mathrm{Zn}^{2+}$ of $\mathrm{C}$. metallidurans $\mathrm{CH} 34$ (blue square) and

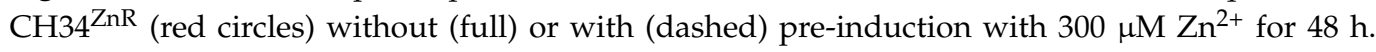
The light grey dotted line represents the detection limit. The average values of three independent experiments with standard deviations are shown. CFU: colony forming unit. 


\subsection{Whole-Genome Expression Profile and Genome Sequence Analysis of $\mathrm{CH} 34^{\mathrm{ZnR}}$}

As the increased resistance stemmed from natural selection of resistance-conferring mutations [53], the global shift in transcriptome resulting from the altered genotype of the evolved strain $\left(\mathrm{CH} 34^{\mathrm{ZnR}}\right)$ as compared to the parental strain was examined in non-selective conditions [54-56]. This revealed 61 coding sequences (CDSs) that were significantly differentially expressed in comparison with the parental CH34 ( $>1 \log _{2}$ fold with an adjusted $p$-value $<0.05$ ), of which 21 were upregulated and 40 downregulated (Table S2). The ABCtype transporter (Rmet_2229_2234) (Figure 2) and the flagellar filament structural protein (fliC2) were the most upregulated genes. The cupRAC operon was the most downregulated, with $\operatorname{copK}$ and $\operatorname{cop} M$ also being downregulated, but no alteration in copper resistance was observed (data not shown). Interestingly, no overlap was observed between the transcriptional profile of $\mathrm{CH} 34^{\mathrm{ZnR}}$ in non-selective conditions and the previously established transcriptional response of the parental $\mathrm{CH} 34$ strain to zinc stress [48].

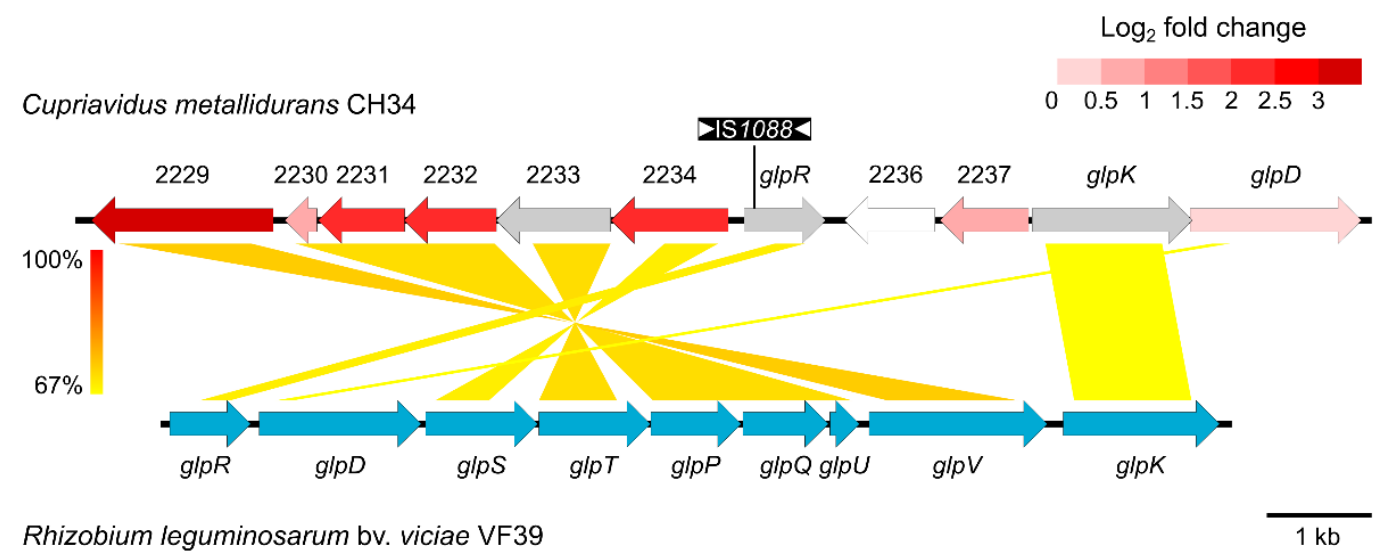

Figure 2. BLASTn comparison of the ABC-type transporter of C. metallidurans $\mathrm{CH} 34 / \mathrm{CH} 34^{\mathrm{ZnR}}$ and the glycerol utilization cluster of the plasmid pRleVF39c from R. leguminosarum bv. viciae VF39 (accession no. JN390944). The colored shading indicates nucleotide identity between the sequences. Coding sequences (CDSs) of $C$. metallidurans $\mathrm{CH} 34$ are color-coded based on their $\log 2$ fold change (CH34 $4^{\mathrm{ZnR}}$ vs. $\mathrm{CH} 34$ expression), with grey being not detected. Insertion of IS1088 in $g l p R$ of $\mathrm{CH} 34^{\mathrm{ZnR}}$ is shown.

Subsequent whole genome sequencing of strain $\mathrm{CH} 34^{\mathrm{ZnR}}$ revealed seven mutations, all of which were caused by transposition of insertion sequences (IS), more specifically ISRme5, ISRme15 and IS1088 (Table 4). Taking into account the expression profile, the inactivation of Rmet_2235 ( $\mathrm{glpR}$ ) by insertion of IS1088 stands out. Therefore, we hypothesized that inactivation of Rmet_2235 resulted in derepressed transcription of the adjacently encoded ABC-type transporter (Rmet_2229-2234) and subsequent increased zinc and cadmium tolerance (Figure 2). This derepression was confirmed by qRT-PCR as transcription of Rmet_2229 was increased 3-fold in CH34 $\Delta g l p R$ compared to the parental CH34 strain (Figure S2). Existing tagRNA-seq data used to identify the $5^{\prime}$ ends of RNAs in C. metallidurans CH34 corroborated that Rmet_2229-2234 was an operon transcribed from the same promoter into one polycistronic mRNA [57]. Furthermore, this dataset indicated that the main transcription start site of the $g l p R$ gene (for strain $\mathrm{CH} 34$ in non-selective growth conditions) was found $9 \mathrm{bp}$ downstream of the currently annotated start codon, indicating translation of a 3-aa shorter GlpR from a leaderless transcript (Figure S3).

A similar gene cluster, also containing a glycerol kinase $(g l p K)$ and glycerol 3-phosphate dehydrogenase $(g l p D)$, was detected in various $\alpha$-proteobacteria enabling utilization of glycerol as a carbon source [58]. In fact, the cluster is similar to the plasmid-borne locus responsible for glycerol utilization from plasmid pRleVF39c in Rhizobium leguminosarum bv. viciae VF39 [58]. In this cluster, the $g l p R$ gene codes for the repressor of the glycerol-3-phosphate regulon and negatively regulates the adjacent genes involved in glycerol metabolism. 
Table 4. Mutations identified in $\mathrm{CH} 34^{\mathrm{ZnR} \text {. }}$

\begin{tabular}{ccc}
\hline Gene & Protein & Inserted Element \\
\hline Rmet_2146 & ABC superfamily transporter subunit & IS1088 \\
Rmet_2171 & Conserved hypothetical protein & ISRme15 \\
Rmet_2235 & DNA-binding transcriptional repressor & IS1088 \\
Rmet_4452 & Response regulator receiver domain protein (CheY-like) & IS1088 \\
Rmet_4521 & Transcriptional regulator & ISRme5 \\
Rmet_4574 & Acyl-CoA dehydrogenase protein & IS1088 \\
Rmet_5200 & Putative glyoxalase/bleomycin resistance & IS1088 \\
& protein/dihydroxy-biphenyl dioxygenase & \\
\hline
\end{tabular}

\subsection{ABC-Type Transporter (Rmet_2229-2234) Is Responsible for Increased Zinc Resistance}

The Rmet_2229_2234 gene cluster was subsequently deleted by replacing it with a tetracycline resistance cassette (referred to as $\Delta 29-34$ ) in both $\mathrm{CH} 34$ and $\mathrm{CH} 34^{\mathrm{ZnR}}$ to test the hypothesis that constitutive derepression of the ABC-type transporter is responsible

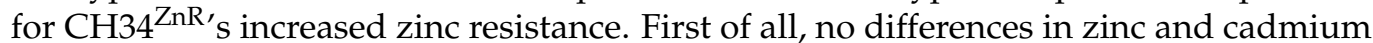
resistance could be observed between $\mathrm{CH} 34 \Delta 29-34$ and its parental strain, indicating that the native $\mathrm{ABC}$-type transporter exerts no role in the detoxification of zinc or cadmium in the parental CH34 strain (Figure 3). However, when the Rmet_2229-2234 gene cluster was deleted in $\mathrm{CH} 34^{\mathrm{ZnR}}$, the zinc and cadmium resistance of the resulting $\mathrm{CH} 34^{\mathrm{ZnR}} \Delta 29$ 34 mutant dropped to levels similar to those of the parental $\mathrm{CH} 34$, indicating that the ABC-type transporter is required for its increased zinc and cadmium resistance (Figure 3). In turn, deletion of the $g l p R$ gene in $\mathrm{CH} 34$ resulted in increased zinc resistance, while plasmid-based complementation of $g l p R$ reduced zinc resistance back to the parental level in both CH34 $\Delta g l p R$ and CH34 ${ }^{\mathrm{ZnR}}$ (Figure 4). The latter further confirms that loss of GlpR function results in increased zinc resistance.

Finally, CH34 $\Delta 29-34$ was still able to utilize glycerol as a sole carbon source (data not shown), demonstrating that the $\mathrm{ABC}$-type transporter is not essential for glycerol uptake in C. metallidurans (contrary to R. leguminosarum bv. viciae VF39).
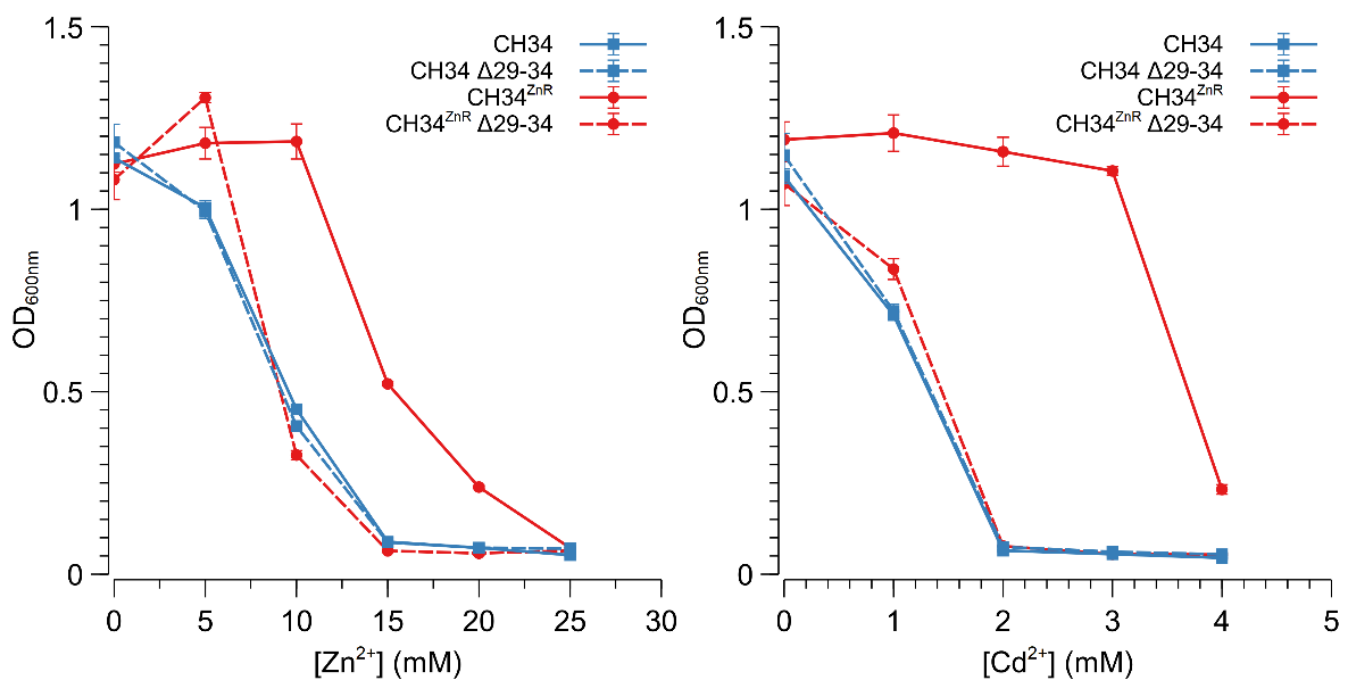

Figure 3. Zinc and cadmium resistance of $\mathrm{C}$. metallidurans $\mathrm{CH} 34$ and its indicated derivatives. Zinc (left) and cadmium (right) dose-response experiments with $\mathrm{CH} 34$ (blue full line, squares), $\mathrm{CH} 34^{\mathrm{ZnR}}$ (red full line, circles) and their $\Delta 29-34$ derivatives (blue dashed line with squares and red dashed line with circles, respectively). The average values of three independent experiments with standard deviations are shown. 


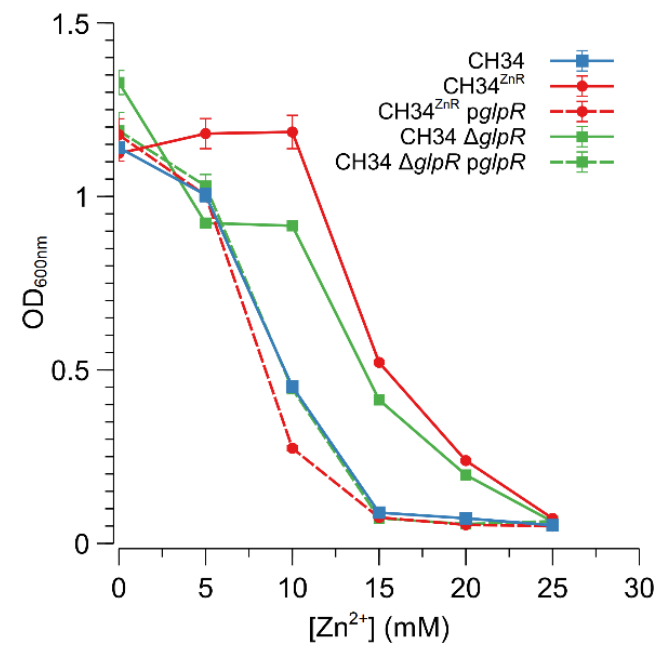

Figure 4. Impact of GlpR function on the increased zinc resistance of C. metallidurans $\mathrm{CH} 34$. Doseresponse experiments with $\mathrm{CH} 34 \Delta g l p R$ (green, squares) and $\mathrm{CH} 34^{\mathrm{ZnR}}$ (red, circles) without (full lines) or with (dashed lines) plasmid-based $g l p R$ complementation. The dose-response experiment with the parental $\mathrm{CH} 34$ strain is shown as a blue line (squares). The average values of three independent experiments with standard deviations are shown.

\subsection{Glycerol Induces Increased Zinc Resistance}

In E. coli, direct interaction with glycerol or glycerol-3-phosphate impedes the action of the GlpR repressor, and thus relieves the repression of the glycerol metabolism [59]. Therefore, C. metallidurans $\mathrm{CH} 34$ and CH34 $\Delta 29-34$ were grown in MM284 containing $1 \%$ $(w / v)$ glycerol to examine if pre-induction with glycerol could promote derepression of the ABC-type transporter and consequently result in increased zinc resistance. Indeed, $\mathrm{CH} 34$ displayed a higher resistance to zinc in the continued presence of glycerol (Figure 5), putatively indicating that binding of GlpR to the operator of the ABC-type transporter is diminished in the presence of glycerol. Furthermore, glycerol had no direct effect on zinc resistance as no increase in zinc resistance was observed for $\mathrm{CH} 34 \Delta$ 29-34 (Figure 5). However, a lower level of zinc resistance was reached for glycerol-induced $\mathrm{CH} 34$ compared to $\mathrm{CH} 34^{\mathrm{ZnR}}$ or $\mathrm{CH} 34 \Delta g l p R$, respectively, suggesting that the presence of glycerol was not sufficient to bind with all available GlpR repressors or that glycerol-GlpR interaction allowed a reduced repression of the ABC-type transporter.

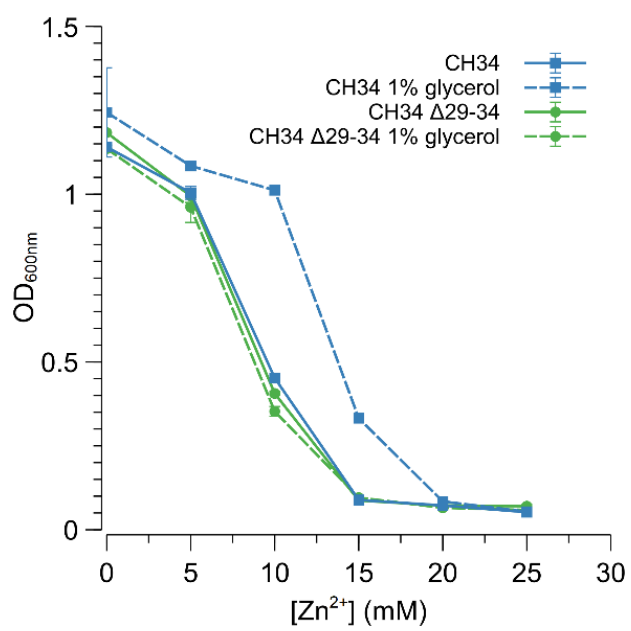

Figure 5. Impact of glycerol on the increased zinc resistance of $C$. metallidurans $\mathrm{CH} 34$. Dose-response experiments with $\mathrm{CH} 34$ (blue) and $\mathrm{CH} 34 \Delta 29-34$ (green) without (full line) and with (dashed line) $1 \%$ glycerol. The average values of three independent experiments with standard deviations are shown. 


\section{Discussion}

This study presents evidence that $C$. metallidurans $\mathrm{CH} 34$ can readily improve its extreme zinc and cadmium resistance through adaptive evolution. It is noteworthy that the high $\mathrm{Zn}^{2+}$ concentrations used resulted in precipitation (of zinc hydroxide) in an abiotic non-inoculated control. Therefore, in the presence of cells there will be a dynamic equilibrium between free $\mathrm{Zn}^{2+}$ ions, protein-bound $\mathrm{Zn}^{2+}$, and precipitation. As correct measurement of free $\mathrm{Zn}^{2+}$ is not straightforward [60], such analyses were out of the scope of this study. However, even without these analyses, the central observation of this study, which is the significant and consequent growth difference between the parental and adapted strain in the presence of high zinc concentrations, remains valid. Moreover, whole genome sequencing, expression profiling, and genetic analysis unexpectedly revealed that insertion sequence-mediated inactivation of the GlpR transcriptional repressor and subsequent upregulation of a neighboring $\mathrm{ABC}$ transporter (not previously involved in metal resistance) were causally responsible for the resistance phenotype.

GlpR belongs to the DeoR-family of transcriptional regulators that are widespread in bacteria and commonly function as specific regulators of carbon source uptake and catabolism, often playing a role in catabolite repression [59,61]. It shares $46 \%$ and $47 \%$ amino acid identity with the GlpR repressor of the glycerol 3-phosphate regulon in E. coli and the glycerol regulon in R. leguminosarum bv. viciae VF39, respectively. Glycerol uptake in R. leguminosarum bv. viciae VF39 is mediated by ABC-type active transport, in contrast to the GlpF-mediated facilitated diffusion in E. coli [62]. Uptake is followed by the enzymatic activity of glycerol kinase $(g l p K)$ and glycerol-3-phosphate dehydrogenase $(g l p D)$, for which expression is negatively regulated by GlpR binding to their operator sequences, enabling the use of glycerol as sole carbon source. In $E$. coli, glpD, but not $g l p K$, is located near $g l p R$. In contrast, in R. leguminosarum bv. viciae VF39, glpD and glpK flank the glpSTPQUV genes coding for an $\mathrm{ABC}$ transporter and form (together with the directly upstream located $g l p R$ ) its plasmid-borne glp operon [58]. In both E. coli and R. leguminosarum, the glycerol utilization regulon is inducible by glycerol and glycerol-3-phosphate via the specific and direct interaction of these metabolites with the GlpR repressor, thereby causing derepression of the glp genes $[58,62]$. In C. metallidurans CH34, glpK (Rmet_2238) and glpD (Rmet_2239) are found in close proximity to $g l p R$ and to the genes coding for the ABC-type transporter (Rmet_2229-2234), although they do not form an operon with the transporter, reflecting a different genomic arrangement than in R. leguminosarum bv. viciae VF39 (Figure 2). Only a slight differential expression of $g l p D$ (1.3-fold) was detected in CH34 ${ }^{\mathrm{ZnR}}$ (expression of glpK could not be determined). As glpK (Rmet_2238) and $g l p D$ (Rmet_2239) likely form an operon (transcription start sites not detected by the existing tagRNA-seq data [57]), it is conceivable that expression of $g l p K$ is also only slightly affected in $\mathrm{CH} 34^{\mathrm{ZnR}}$. In contrast to the derepression of the ABC-type transporter (Rmet_2229-2234), these data do not univocally show GlpR-mediated regulation of glpKD (Rmet_2238-39) in C. metallidurans. In addition, CH34 carries a second locus containing a $g l p K$ (Rmet_5445) and $g l p D$ (Rmet_5444) gene, as well as genes coding for a putative glycerol uptake operon antiterminator regulatory protein (Rmet_5442), a putative akylglycerone-phosphate synthase (Rmet_5443), and a Major Facilitator Superfamily (MFS) transporter (Rmet_5446). However, none of the genes in this second glp locus are differentially expressed in $\mathrm{CH} 34^{\mathrm{ZnR}}$. Furthermore, as glycerol can still be used as sole carbon source in the absence of the ABC-type transporter (CH34 $\Delta 29-34)$, other glycerol transporters exist, e.g., the MFS transporter in the second glp locus (Rmet_5446).

The ABC-type transporter responsible for increased zinc and cadmium resistance in $\mathrm{CH} 34^{\mathrm{ZnR}}$ comprises six proteins that are encoded by Rmet_2229 up to Rmet_2234. More specifically, one periplasmic protein, one small integral membrane protein, two permeases, and two ATPases form the $\mathrm{ABC}$ transporter. The six genes encoding the $\mathrm{ABC}$ transporter resemble the glycerol ABC transporter operon of $R$. leguminosarum bv. viciae VF39, with for instance $63 \%$ amino acid identity between the periplasmic protein encoded by Rmet_2229 of CH34 and $g l p V$ of VF39 [58]. These similarities clearly indicate a role in glycerol uptake 
for this uncharacterized ABC-type transporter. In fact, addition of glycerol to the growth medium improved zinc resistance in a Rmet_2229-2234-dependent fashion, indicating a role for glycerol-mediated relief of repression of the ABC-type transporter. This observation therefore reveals that bacterial metal resistance can also depend on the exact carbon sources in the environment.

$\mathrm{ABC}$ transporters are found in all taxa and form one of the largest transporter superfamilies, containing both uptake and efflux transport systems. These transporters couple hydrolysis of ATP to the translocation of various substrates, ranging from single ions to entire protein toxins, across cell membranes [63]. The best-studied metal ABC transporter is the high-affinity $\mathrm{Zn}^{2+}$ uptake system encoded by the $z n u A B C$ genes and regulated by Zur, which was initially reported in E. coli [20]. ZnuB is the membrane permease and ZnuC is the ATPase component of the transporter, whereas ZnuA is a soluble periplasmic metallochaperone that efficiently captures zinc in this cellular compartment and then delivers the metal to the transmembrane component of the transporter [64]. In contrast to eukaryotes, no examples of $\mathrm{ABC}$ transporters involved in metal export are known in bacteria. Nevertheless, ABC transporters that export substrates (which are still to be elucidated) to the periplasm could mediate the repair of metal-induced protein damage [65].

Based on its similarity to the glycerol utilization operon of R. leguminosarum bv. viciae VF39, the Rmet_2229-2234 transporter is likely an uptake system, and the exact mechanism underlying the observed zinc and cadmium resistance requires further study. Nevertheless, a few hypotheses could be formulated that might explain preventing excess zinc and cadmium in the cytoplasm. The imported substrates or the metabolism of these substrates might yield binding sites for metals $[66,67]$. However, no glycerol or sugars were added to the selective medium. Alternatively, the increased pool of periplasmic binding proteins could bind $\mathrm{Zn}^{2+}\left(\mathrm{Cd}^{2+}\right)$ and prevent entry into the cytoplasm. Lastly, released inorganic phosphate $\left(\mathrm{P}_{\mathrm{i}}\right)$ by ATP hydrolysis might bind excess $\mathrm{Zn}^{2+}\left(\mathrm{Cd}^{2+}\right)$, resulting in phosphatezinc conjugates [68].

Finally, it is noteworthy that all of the mutations incurred by $\mathrm{CH} 34^{\mathrm{ZnR}}$ were caused by the transposition of different insertion sequences (more specifically ISRme5, ISRme15, and IS1088), underscoring the dynamic nature of these elements. Moreover, we have recently shown zinc-induced promoter activity for the transposases of ISRme5 and IS1088 [69], indicating that IS dynamics can be boosted in times of stress to provide evolutionary escape routes for the host cell $[69,70]$.

\section{Conclusions}

To conclude, we have demonstrated that derepression of the inconspicuous Rmet_22292234 ABC-type transporter (which is likely involved in glycerol uptake) can serve as an evolutionary road towards extreme zinc and cadmium resistance in C. metallidurans CH34. Moreover, Rmet_2229-2234-mediated protection against zinc can also become environmentally triggered in the presence of glycerol. Finally, our observations also underscore the importance of IS elements in the adaptive potential of C. metallidurans CH34.

Supplementary Materials: The following are available online at https://www.mdpi.com/2076-2 607/9/2/309/s1, Figure S1: Zinc dose-response experiments with $\mathrm{CH} 34$ (blue) and $\mathrm{CH} 34^{\mathrm{ZnR}}$ (red). The abiotic (non-inoculated) control is shown in green. The average values of three independent experiments with standard deviations are shown. Figure S2: Relative fold change determined by quantitative real-time PCR (qRT-PCR) analysis of Rmet_2229 in CH34 DglpR and CH34 ${ }^{\text {ZnR }}$. All data were normalized with $16 \mathrm{~S}$ rRNA gene expression and given as relative to the parental CH34 strain. Figure S3: Transcription profile analysis of the Rmet_2234-glpR intergenic region from C. metallidurans $\mathrm{CH} 34$ (coordinates for the chromosomal region are shown at the bottom). Combined transcription start site (TSS) read counts of the three biological replicates are shown for positive (green) and negative (red) strands. The small black arrows indicate clearly identified primary and internal TSSs. The green arrow represents a re-annotated CDS. Data from [57], Table S1: Primers used in this study, Table S2: Differential gene expression analysis results. 
Author Contributions: Conceptualization, R.V.H. and A.A.; methodology, R.V.H., J.V. and A.A.; validation, R.V.H., J.V. and P.M.; formal analysis, R.V.H., J.V. and P.M.; investigation, R.V.H., J.V. and P.M.; data curation, R.V.H.; writing—original draft preparation, R.V.H. and J.V.; writing-review and editing, R.V.H. and A.A.; visualization, R.V.H.; supervision, R.V.H. and A.A.; project administration, N.L. All authors have read and agreed to the published version of the manuscript.

Funding: This research received no external funding.

Institutional Review Board Statement: Not applicable.

Informed Consent Statement: Not applicable.

Data Availability Statement: The full description of the microarray data has been deposited at the Gene Expression Omnibus website (http:/ / www.ncbi.nlm.nih.gov/geo/) under accession number GSE156826. Sequencing data are available within the Sequencing Read Archive (SRA) of NCBI using the accession number PRJNA658861.

Conflicts of Interest: The authors declare no conflict of interest.

\section{References}

1. Moore, C.M.; Helmann, J.D. Metal ion homeostasis in Bacillus subtilis. Curr. Opin. Microbiol. 2005, 8, 188-195. [CrossRef] [PubMed]

2. Hobman, J.; Yamamoto, K.; Oshima, T. Transcriptomic Responses of Bacterial Cells to Sublethal Metal Ion Stress. In Molecular Microbiology of Heavy Metals; Nies, D., Silver, S., Eds.; Springer: Berlin/Heidelberg, Gemany, 2007; Volume 6, pp. 73-115.

3. Nies, D.H. The biological chemistry of the transition metal "transportome" of Cupriavidus metallidurans. Metallomics 2016, 8 , 481-507. [CrossRef] [PubMed]

4. Hantke, K. Bacterial zinc transporters and regulators. BioMetals 2001, 14, 239-249. [CrossRef] [PubMed]

5. Staicu, L.C.; Wojtowicz, P.J.; Pósfai, M.; Pekker, P.; Gorecki, A.; Jordan, F.L.; Barton, L.L. PbS biomineralization using cysteine: Bacillus cereus and the sulfur rush. FEMS Microbiol. Ecol. 2020, 96, fiaa151. [CrossRef] [PubMed]

6. Dopson, M.; Baker-Austin, C.; Koppineedi, P.R.; Bond, P.L. Growth in sulfidic mineral environments: Metal resistance mechanisms in acidophilic micro-organisms. Microbiology 2003, 149, 1959-1970. [CrossRef]

7. Monsieurs, P.; Hobman, J.; Vandenbussche, G.; Mergeay, M.; Van Houdt, R. Response of Cupriavidus metallidurans to Metals. In Metal Response in Cupriavidus Metallidurans, Volume I: From Habitats to Genes and Proteins; Mergeay, M., Van Houdt, R., Eds.; Springer International Publishing: Cham, Switzerland, 2015; pp. 45-89.

8. Grosse, C.; Friedrich, S.; Nies, D.H. Contribution of extracytoplasmic function sigma factors to transition metal homeostasis in Cupriavidus metallidurans strain CH34. J. Mol. Microbiol. Biotechnol. 2007, 12, 227-240. [CrossRef]

9. Malle, K.G. Zink in der Umwelt. Acta Hydrochim. Hydrobiol. 1992, 20, 196-204. [CrossRef]

10. Tan, S.Y.; Praveena, S.M.; Abidin, E.Z.; Cheema, M.S. A review of heavy metals in indoor dust and its human health-risk implications. Rev. Environ. Health 2016, 31, 447-456. [CrossRef]

11. Gillan, D.C.; Van Camp, C.; Mergeay, M.; Provoost, A.; Thomas, N.; Vermard, L.; Billon, G.; Wattiez, R. Paleomicrobiology to investigate copper resistance in bacteria: Isolation and description of Cupriavidus necator B9 in the soil of a medieval foundry. Environ. Microbiol. 2017, 19, 770-787. [CrossRef]

12. John, M.; Heuss-Aßbichler, S.; Ullrich, A. Recovery of Zn from wastewater of zinc plating industry by precipitation of doped ZnO nanoparticles. Int. J. Environ. Sci. Technol. 2016, 13, 2127-2134. [CrossRef]

13. Gillan, D.C.; Van Houdt, R. The Impact of Metal Contamination on Soil Microbial Community Dynamics. In Modern Soil Microbiology, 3rd ed.; Van Elsas, J.D., Trevors, J.T., Rosado, A.S., Nannipieri, A., Eds.; CRC Press: Boca Raton, FL, USA, 2019; pp. 403-419.

14. Kabata-Pendias, A. Trace Elements in Soils and Plants, 4th ed.; CRC Press: Boca Raton, FL, USA, 2010; p. 548.

15. Ellis, R.J.; Morgan, P.; Weightman, A.J.; Fry, J.C. Cultivation-Dependent and -Independent Approaches for Determining Bacterial Diversity in Heavy-Metal-Contaminated Soil. Appl. Environ. Microbiol. 2003, 69, 3223-3230. [CrossRef] [PubMed]

16. Rogiers, T.; Claesen, J.; Van Gompel, A.; Vanhoudt, N.; Mysara, M.; Williamson, A.; Leys, N.; Van Houdt, R.; Boon, N.; Mijnendonckx, K. Soil microbial community structure and functionality changes in response to long-term metal and radionuclide pollution. Environ. Microbiol. 2021. [CrossRef] [PubMed]

17. Frassinetti, S.; Bronzetti, G.; Caltavuturo, L.; Cini, M.; Croce, C.D. The role of zinc in life: A review. J. Environ. Pathol. Toxicol. Oncol. 2006, 25, 597-610. [CrossRef] [PubMed]

18. Blencowe, D.K.; Morby, A.P. Zn(II) metabolism in prokaryotes. FEMS Microbiol. Rev. 2003, 27, 291-311. [CrossRef]

19. Mergeay, M.; Nies, D.; Schlegel, H.G.; Gerits, J.; Charles, P.; Vangijsegem, F. Alcaligenes eutrophus CH34 is a facultative chemolithotroph with plasmid-bound resistance to heavy-metals. J. Bacteriol. 1985, 162, 328-334. [CrossRef]

20. Patzer, S.I.; Hantke, K. The ZnuABC high-affinity zinc uptake system and its regulator Zur in Escherichia coli. Mol. Microbiol. 1998, 28, 1199-1210. [CrossRef]

21. Saier, M.H., Jr.; Tran, C.V.; Barabote, R.D. TCDB: The Transporter Classification Database for membrane transport protein analyses and information. Nucleic Acids Res. 2006, 34, D181-D186. [CrossRef] 
22. Herzberg, M.; Bauer, L.; Nies, D.H. Deletion of the zupT gene for a zinc importer influences zinc pools in Cupriavidus metallidurans CH34. Metallomics 2014, 6, 421-436. [CrossRef]

23. Kirsten, A.; Herzberg, M.; Voigt, A.; Seravalli, J.; Grass, G.; Scherer, J.; Nies, D.H. Contributions of five secondary metal uptake systems to metal homeostasis of Cupriavidus metallidurans CH34. J. Bacteriol. 2011, 193, 4652-4663. [CrossRef]

24. Schmidt, C.; Schwarzenberger, C.; Grosse, C.; Nies, D.H. FurC regulates expression of zupT for the central zinc importer ZupT of Cupriavidus metallidurans. J. Bacteriol. 2014, 196, 3461-3471. [CrossRef]

25. Janssen, P.J.; Van Houdt, R.; Moors, H.; Monsieurs, P.; Morin, N.; Michaux, A.; Benotmane, M.A.; Leys, N.; Vallaeys, T.; Lapidus, A.; et al. The complete genome sequence of Cupriavidus metallidurans strain $\mathrm{CH} 34$, a master survivalist in harsh and anthropogenic environments. PLoS ONE 2010, 5, e10433. [CrossRef] [PubMed]

26. Mergeay, M.; Monchy, S.; Vallaeys, T.; Auquier, V.; Benotmane, A.; Bertin, P.; Taghavi, S.; Dunn, J.; van der Lelie, D.; Wattiez, R. Ralstonia metallidurans, a bacterium specifically adapted to toxic metals: Towards a catalogue of metal-responsive genes. FEMS Microbiol. Rev. 2003, 27, 385-410. [CrossRef]

27. Nies, D.H. Efflux-mediated heavy metal resistance in prokaryotes. FEMS Microbiol. Rev. 2003, 27, 313-339. [CrossRef]

28. Diels, L.; Van Roy, S.; Taghavi, S.; Van Houdt, R. From industrial sites to environmental applications with Cupriavidus metallidurans Antonie van Leeuwenhoek 2009, 96, 247-258. [CrossRef] [PubMed]

29. Hynninen, A.; Touze, T.; Pitkanen, L.; Mengin-Lecreulx, D.; Virta, M. An efflux transporter PbrA and a phosphatase PbrB cooperate in a lead-resistance mechanism in bacteria. Mol. Microbiol. 2009, 74, 384-394. [CrossRef] [PubMed]

30. Grosse, C.; Grass, G.; Anton, A.; Franke, S.; Santos, A.N.; Lawley, B.; Brown, N.L.; Nies, D.H. Transcriptional organization of the czc heavy-metal homeostasis determinant from Alcaligenes eutrophus. J. Bacteriol. 1999, 181, 2385-2393. [CrossRef]

31. Nies, D.; Mergeay, M.; Friedrich, B.; Schlegel, H.G. Cloning of plasmid genes encoding resistance to cadmium, zinc, and cobalt in Alcaligenes eutrophus CH34. J. Bacteriol. 1987, 169, 4865-4868. [CrossRef]

32. Tseng, T.T.; Gratwick, K.S.; Kollman, J.; Park, D.; Nies, D.H.; Goffeau, A.; Saier, M.H., Jr. The RND permease superfamily: An ancient, ubiquitous and diverse family that includes human disease and development proteins. J. Mol. Microbiol. Biotechnol. 1999, 1, 107-125.

33. Vandenbussche, G.; Mergeay, M.; Van Houdt, R. Metal Response in Cupriavidus Metallidurans, Volume II: Insights into the StructureFunction Relationship of Proteins; Springer International Publishing: Cham, Switzerland, 2015.

34. Rensing, C.; Pribyl, T.; Nies, D.H. New functions for the three subunits of the CzcCBA cation-proton antiporter. J. Bacteriol. 1997, 179, 6871-6879. [CrossRef]

35. Seeger, M.A.; Schiefner, A.; Eicher, T.; Verrey, F.; Diederichs, K.; Pos, K.M. Structural asymmetry of AcrB trimer suggests a peristaltic pump mechanism. Science 2006, 313, 1295-1298. [CrossRef]

36. Murakami, S.; Nakashima, R.; Yamashita, E.; Matsumoto, T.; Yamaguchi, A. Crystal structures of a multidrug transporter reveal a functionally rotating mechanism. Nature 2006, 443, 173-179. [CrossRef]

37. Lomovskaya, O.; Totrov, M. Vacuuming the periplasm. J Bacteriol 2005, 187, 1879-1883. [CrossRef] [PubMed]

38. Scherer, J.; Nies, D.H. CzcP is a novel efflux system contributing to transition metal resistance in Cupriavidus metallidurans CH34. Mol. Microbiol. 2009, 73, 601-621. [CrossRef]

39. van der Lelie, D.; Schwuchow, T.; Schwidetzky, U.; Wuertz, S.; Baeyens, W.; Mergeay, M.; Nies, D.H. Two-component regulatory system involved in transcriptional control of heavy-metal homoeostasis in Alcaligenes eutrophus. Mol. Microbiol. 1997, 23, 493-503. [CrossRef] [PubMed]

40. Legatzki, A.; Grass, G.; Anton, A.; Rensing, C.; Nies, D.H. Interplay of the Czc system and two P-type ATPases in conferring metal resistance to Ralstonia metallidurans. J. Bacteriol. 2003, 185, 4354-4361. [CrossRef] [PubMed]

41. Munkelt, D.; Grass, G.; Nies, D.H. The chromosomally encoded cation diffusion facilitator proteins DmeF and FieF from Wautersia metallidurans CH34 are transporters of broad metal specificity. J. Bacteriol. 2004, 186, 8036-8043. [CrossRef]

42. De Angelis, F.; Lee, J.K.; O’Connell, J.D., 3rd; Miercke, L.J.; Verschueren, K.H.; Srinivasan, V.; Bauvois, C.; Govaerts, C.; Robbins, R.A.; Ruysschaert, J.M.; et al. Metal-induced conformational changes in ZneB suggest an active role of membrane fusion proteins in efflux resistance systems. Proc. Natl. Acad. Sci. USA 2010, 107, 11038-11043. [CrossRef] [PubMed]

43. Pak, J.E.; Ekende, E.N.; Kifle, E.G.; O’Connell, J.D., 3rd; De Angelis, F.; Tessema, M.B.; Derfoufi, K.M.; Robles-Colmenares, Y.; Robbins, R.A.; Goormaghtigh, E.; et al. Structures of intermediate transport states of ZneA, a Zn(II)/proton antiporter. Proc. Natl. Acad. Sci. USA 2013, 110, 18484-18489. [CrossRef]

44. Mergeay, M.; Van Houdt, R. Metal Response in Cupriavidus Metallidurans: Volume I: From Habitats to Genes and Proteins; Springer International Publishing: Cham, Switzerland, 2015.

45. Kovach, M.E.; Elzer, P.H.; Hill, D.S.; Robertson, G.T.; Farris, M.A.; Roop, R.M., 2nd; Peterson, K.M. Four new derivatives of the broad-host-range cloning vector pBBR1MCS, carrying different antibiotic-resistance cassettes. Gene 1995, 166, 175-176. [CrossRef]

46. Chang, A.C.; Cohen, S.N. Construction and characterization of amplifiable multicopy DNA cloning vehicles derived from the p15A cryptic miniplasmid. J. Bacteriol. 1978, 134, 1141-1156. [CrossRef]

47. Katzen, F.; Becker, A.; Ielmini, M.V.; Oddo, C.G.; Ielpi, L. New mobilizable vectors suitable for gene replacement in gram-negative bacteria and their use in mapping of the $3^{\prime}$ end of the Xanthomonas campestris pv. campestris gum operon. Appl. Environ. Microb. 1999, 65, 278-282. [CrossRef] [PubMed] 
48. Monsieurs, P.; Moors, H.; Van Houdt, R.; Janssen, P.J.; Janssen, A.; Coninx, I.; Mergeay, M.; Leys, N. Heavy metal resistance in Cupriavidus metallidurans CH34 is governed by an intricate transcriptional network. BioMetals 2011, 24, 1133-1151. [CrossRef] [PubMed]

49. DePristo, M.A.; Banks, E.; Poplin, R.; Garimella, K.V.; Maguire, J.R.; Hartl, C.; Philippakis, A.A.; del Angel, G.; Rivas, M.A.; Hanna, M.; et al. A framework for variation discovery and genotyping using next-generation DNA sequencing data. Nat. Genet. 2011, 43, 491-498. [CrossRef] [PubMed]

50. McKenna, A.; Hanna, M.; Banks, E.; Sivachenko, A.; Cibulskis, K.; Kernytsky, A.; Garimella, K.; Altshuler, D.; Gabriel, S.; Daly, M.; et al. The Genome Analysis Toolkit: A MapReduce framework for analyzing next-generation DNA sequencing data. Genome Res. 2010, 20, 1297-1303. [CrossRef] [PubMed]

51. Nies, D.H. CzcR and CzcD, gene products affecting regulation of resistance to cobalt, zinc, and cadmium (czc system) in Alcaligenes eutrophus. J. Bacteriol. 1992, 174, 8102-8110. [CrossRef] [PubMed]

52. Monchy, S.; Benotmane, M.A.; Janssen, P.; Vallaeys, T.; Taghavi, S.; van der Lelie, D.; Mergeay, M. Plasmids pMOL28 and pMOL30 of Cupriavidus metallidurans are specialized in the maximal viable response to heavy metals. J. Bacteriol. 2007, 189, 7417-7425. [CrossRef] [PubMed]

53. Lenski, R.E. What is adaptation by natural selection? Perspectives of an experimental microbiologist. PLoS Genet. 2017, 13, e1006668. [CrossRef]

54. LaCroix, R.A.; Sandberg, T.E.; O’Brien, E.J.; Utrilla, J.; Ebrahim, A.; Guzman, G.I.; Szubin, R.; Palsson, B.O.; Feist, A.M. Use of adaptive laboratory evolution to discover key mutations enabling rapid growth of Escherichia coli K-12 MG1655 on glucose minimal medium. Appl. Environ. Microbiol. 2015, 81, 17-30. [CrossRef]

55. McCloskey, D.; Xu, S.; Sandberg, T.E.; Brunk, E.; Hefner, Y.; Szubin, R.; Feist, A.M.; Palsson, B.O. Growth Adaptation of gnd and sdhCB Escherichia coli Deletion Strains Diverges From a Similar Initial Perturbation of the Transcriptome. Front. Microbiol. 2018, 9, 1793. [CrossRef]

56. Sandberg, T.E.; Pedersen, M.; LaCroix, R.A.; Ebrahim, A.; Bonde, M.; Herrgard, M.J.; Palsson, B.O.; Sommer, M.; Feist, A.M. Evolution of Escherichia coli to 42 degrees $C$ and subsequent genetic engineering reveals adaptive mechanisms and novel mutations. Mol. Biol. Evol. 2014, 31, 2647-2662. [CrossRef]

57. Maertens, L.; Leys, N.; Matroule, J.Y.; Van Houdt, R. The Transcriptomic Landscape of Cupriavidus metallidurans CH34 Acutely Exposed to Copper. Genes 2020, 11, 1049. [CrossRef] [PubMed]

58. Ding, H.; Yip, C.B.; Geddes, B.A.; Oresnik, I.J.; Hynes, M.F. Glycerol utilization by Rhizobium leguminosarum requires an ABC transporter and affects competition for nodulation. Microbiology 2012, 158, 1369-1378. [CrossRef] [PubMed]

59. Zeng, G.; Ye, S.; Larson, T.J. Repressor for the sn-glycerol 3-phosphate regulon of Escherichia coli K-12: Primary structure and identification of the DNA-binding domain. J. Bacteriol. 1996, 178, 7080-7089. [CrossRef] [PubMed]

60. Ollig, J.; Kloubert, V.; Weßels, I.; Haase, H.; Rink, L. Parameters Influencing Zinc in Experimental Systems in Vivo and in Vitro. Metals 2016, 6, 71. [CrossRef]

61. Martin, J.H.; Sherwood Rawls, K.; Chan, J.C.; Hwang, S.; Martinez-Pastor, M.; McMillan, L.J.; Prunetti, L.; Schmid, A.K.; MaupinFurlow, J.A. GlpR Is a Direct Transcriptional Repressor of Fructose Metabolic Genes in Haloferax volcanii. J. Bacteriol. 2018, 200, e00218-e00244. [CrossRef]

62. Lin, E.C. Glycerol dissimilation and its regulation in bacteria. Annu. Rev. Microbiol. 1976, 30, 535-578. [CrossRef]

63. Saier, M.H., Jr. A functional-phylogenetic classification system for transmembrane solute transporters. Microbiol. Mol. Biol. Rev. 2000, 64, 354-411. [CrossRef]

64. Ammendola, S.; Pasquali, P.; Pistoia, C.; Petrucci, P.; Petrarca, P.; Rotilio, G.; Battistoni, A. High-affinity Zn ${ }^{2+}$ uptake system Znu$\mathrm{ABC}$ is required for bacterial zinc homeostasis in intracellular environments and contributes to the virulence of Salmonella enterica. Infect. Immun. 2007, 75, 5867-5876. [CrossRef]

65. Mikolay, A.; Nies, D.H. The ABC-transporter AtmA is involved in nickel and cobalt resistance of Cupriavidus metallidurans strain CH34. Antonie Van Leeuwenhoek 2009, 96, 183-191. [CrossRef]

66. Edgar, R.J.; van Hensbergen, V.P.; Ruda, A.; Turner, A.G.; Deng, P.; Le Breton, Y.; El-Sayed, N.M.; Belew, A.T.; McIver, K.S.; McEwan, A.G.; et al. Discovery of glycerol phosphate modification on streptococcal rhamnose polysaccharides. Nat. Chem. Biol. 2019, 15, 463-471. [CrossRef]

67. Newsome, L.; Morris, K.; Trivedi, D.; Bewsher, A.; Lloyd, J.R. Biostimulation by Glycerol Phosphate to Precipitate Recalcitrant Uranium(IV) Phosphate. Environ. Sci. Technol. 2015, 49, 11070-11078. [CrossRef] [PubMed]

68. Sarret, G.; Saumitou-Laprade, P.; Bert, V.; Proux, O.; Hazemann, J.L.; Traverse, A.; Marcus, M.A.; Manceau, A. Forms of zinc accumulated in the hyperaccumulator Arabidopsis halleri. Plant Physiol. 2002, 130, 1815-1826. [CrossRef]

69. Vandecraen, J.; Monsieurs, P.; Mergeay, M.; Leys, N.; Aertsen, A.; Van Houdt, R. Zinc-induced transposition of insertion sequence elements contributes to increased adaptability of Cupriavidus metallidurans. Front. Microbiol. 2016, 7, 359. [CrossRef] [PubMed]

70. Vandecraen, J.; Chandler, M.; Aertsen, A.; Van Houdt, R. The impact of insertion sequences on bacterial genome plasticity and adaptability. Crit. Rev. Microbiol. 2017, 43, 709-730. [CrossRef] [PubMed] 